\title{
THE INDIAN VIEW OF ECONOMIC DEVELOPMENT: Resilience and the Quest for Growth
}

\author{
Raghbendra Jha \\ Australia South Asia Research Centre, \\ Research School of Pacific and Asian Studies, \\ The Australian National University
}

Keywords: India, Economic Growth, Resilience to Shocks

JEL Classification Code: B22, E21, E66, N15

All correspondence to:

Prof. Raghbendra Jha, Australia South Asia Research Centre, Research School of Pacific and Asian Studies, The Australian National University, Canberra, ACT 0200, Australia

Fax: + 61261250443

Email: r.jha@anu.edu.au 


\section{Introduction}

India's economic growth for much of the period since independence was described as being characterized by "the Hindu rate of growth" — a term coined by the economist Raj Krishna and popularised by the former World Bank Chief Robert McNamara. Real GDP grew at about 3.5 per cent per annum on average in contrast to several other developing countries, particulalry in East and South-East Asia, that were growing much faster. Since the mid 1980s, however, India has surprised many commentators by clocking much higher, of late, even accelerating rates of growth. This higher growth has not come too soon. With more than 250 million Indians living in conditions of abject poverty and given widespread acceptance of the proposition that economic growth is the most trusted means of poverty reduction, the recent surge in Indian economic growth has kindled hopes that Indians may soon experience substantial improvements in living standards and that India may yet become an important economic player in the global economy.

Viewed over a longer horizon this metamorphosis of India’s growth indicates not a rate of growth but an Indian view of growth which may be described as resilience to adverse conditions and concomitant quest for higher growth. India's quest for high economic growth has been a constant, if sometimes apparently dormant, denominator of national activity and has had to adapt itself to conditions both within the economy as well as abroad, but has never really been abandoned.

To be sure, spurts of high growth in various countries have fizzled out whence, in hindsight, some high growth experiences, like that of Japan in the 1980s, have been characterised as bubbles. Some such bubbles have lasted longer than others, e.g., the high growth phase of the South East Asian economies, and have led to sharp drops in 
poverty. However, these are all small countries with populations much smaller than India's (which currently stands at over 1.1 billion). China's accelerating growth rate and rapidly declining poverty in the past 30 years or so lent credence to the hypothesis that a country comparable in geographical size, population and scale of poverty to India could successfully use higher economic growth to address problems of mass deprivation. But, there is one major difference - India is a vibrant multiparty democracy with a free press, China is not. This difference leads to what some have called "excessive” delays in decision-making in India resulting in slow pace of economic reforms. Thus India’s quest for higher growth is unique. So is its approach.

The central theme of this chapter is that the Indian economy has been remarkably resilient and been able to adapt its quest for growth to changes in circumstances in both the domestic and the global economy and is now poised for sustained progress. At the time of independence after centuries of stagnation, even decline, India's confidence and society stood shaken. The licence quota raj ensured that three decades of unimpressive growth followed even as developing East and Southeast Asia were surging ahead. Yet once the controls were slackened the Indian economy was able to discover its innate vitality. Growth has remained high since the mid 1980s and has even started to accelerate of late, albeit with a few short-run drops.

This chapter is an account of the resilience of the Indian economy as well as its quest for higher rates of growth. In the process the Indian economy and society are being transformed and there are clear signs of a much stronger player emerging on the global stage in the near future. The plan of this chapter is as follows. It provides a historical backdrop for India’s growth experience in section II, emphasizing the resilience of the economy to adverse shocks over a period of almost 400 years and the pick-up of 
economic growth once some of these constraints were lifted. Section III discusses some factors contributing to the acceleration in India's growth rate. Section IV outlines India's performance in external trade and section $\mathrm{V}$ presents two faces of the new India - a dynamic sector (automobiles) and a laggard (agriculture). Section VI concludes.

\section{India's Growth Experience in Historical Perspective}

By all accounts from the $15^{\text {th }}$ to the $18^{\text {th }}$ century India was one of the most prosperous regions of the world with plentiful supply of highly advanced commercial and industrial techniques (Clydesdale 2007). From 1700, however, Indian GDP per capita started to drop. For more than 400 years now India has had low incomes and low, even negative, rates of economic growth whereas its population has continued to expand. Table 1 compares real per capita GDP and GDP in 1990 international dollars and population between India and the United Kingdom over the period 1600 to 1947, when India attained independence from British rule.

Table 1: Comparative Macroeconomic Performance of India and Britain, 1600-1947

\begin{tabular}{|c|c|c|c|c|c|}
\hline & 1600 & 1700 & 1757 & 1857 & 1947 \\
\hline & \multicolumn{5}{|c|}{ Per Capita GDP (1990 international dollars) } \\
\hline India & 550 & 550 & 540 & 520 & 618 \\
\hline \multirow[t]{2}{*}{ United Kingdom } & 974 & 1250 & 1424 & 2717 & 6361 \\
\hline & \multicolumn{5}{|c|}{ Population (000) } \\
\hline India & 135000 & 165000 & 185000 & 227000 & 414000 \\
\hline \multirow[t]{2}{*}{ United Kingdom } & 6170 & 8565 & 13180 & 28187 & 49519 \\
\hline & \multicolumn{5}{|c|}{ GDP (million 1990 international dollars) } \\
\hline India & 74250 & 90750 & 99900 & 118040 & 255852 \\
\hline United Kingdom & 6007 & 10709 & 18768 & 76584 & 314969 \\
\hline
\end{tabular}

Source: Maddison (2006).

India's per capita GDP which in 1600 was more than half of the UK's, remained stagnant and even fell for a while during the period until 1947 at which time UK's per capita GDP was more than 10 times that of India. Taking 1757 as an approximate date 
for the beginning of British rule in India the ratio of UK's per capita GDP to Indian GDP grew from 2.63 in 1757 to 5.22 in 1857 and 10.29 in 1947. Over the same period the ratio of India's population to British population fell from 14.03 in 1757 to 8.05 in 1857 and only marginally rose to 8.36 in 1947 . The ratio of British absolute GDP to Indian GDP was 0.187 in 1757, but rose to 0.648 in 1857 . By 1947 British GDP had overtaken Indian GDP and the ratio between them stood at 1.23.

However, India's colonial experience was not unique in that most colonies that did not result in settlements had poor records of economic growth with stagnation for long periods of time (Tables 2 and 3). Table 2 shows levels of GDP per capita in the major European colonial powers and some colonies for about 500 years. Table 3 provides information on growth rates in the same countries.

Table 2: Levels of GDP per capita in European Colonial Powers and Former Colonies, 1500-1998 (1990 international dollars)

\begin{tabular}{|l|c|r|r|r|r|r|}
\hline & 1500 & 1700 & 1820 & 1913 & 1950 & 1998 \\
\hline & \multicolumn{5}{|l|}{ European Colonial Powers } \\
\hline Britain & 762 & 1405 & 2121 & 5150 & 6907 & 18714 \\
\hline France & 727 & 986 & 1230 & 3485 & 5270 & 19558 \\
\hline Italy & 1100 & 1100 & 1117 & 2564 & 3502 & 17759 \\
\hline Netherlands & 754 & 2110 & 1821 & 4049 & 5996 & 20224 \\
\hline Portugal & 632 & 854 & 963 & 1244 & 2069 & 12929 \\
\hline Spain & 698 & 900 & 1063 & 2255 & 2397 & 14227 \\
\hline & Former Colonies & & & & & \\
\hline China & 600 & 600 & 600 & 552 & 439 & 3117 \\
\hline India & 550 & 550 & 533 & 673 & 619 & 1746 \\
\hline Indonesia & 565 & 580 & 612 & 904 & 840 & 3070 \\
\hline Brazil & 400 & 460 & 646 & 811 & 1672 & 5459 \\
\hline Mexico & 425 & 568 & 759 & 1732 & 2365 & 6655 \\
\hline United States & 526 & 715 & 880 & 2736 & 3446 & 18183 \\
\hline
\end{tabular}

Source: Maddison (2006). 
Table 3: Growth of per capita GDP in European Colonial Powers and Former Colonies, 1500-1998 (annual average compound growth rates)

\begin{tabular}{|l|c|c|c|c|c|}
\hline & $1500-1700$ & $1700-1820$ & $1820-1913$ & $1913-1950$ & $1950-1998$ \\
\hline & \multicolumn{5}{|l|}{ European Colonial Powers } \\
\hline Britain & 0.31 & 0.34 & 0.96 & 0.80 & 2.12 \\
\hline France & 0.15 & 0.18 & 1.13 & 0.85 & 2.77 \\
\hline Italy & 0.00 & 0.01 & 0.90 & 1.07 & 2.44 \\
\hline Netherlands & 0.52 & -0.12 & 0.86 & 1.38 & 3.89 \\
\hline Portugal & 0.15 & 0.10 & 0.27 & 0.17 & 3.78 \\
\hline Spain & 0.13 & 0.14 & 0.81 & & \\
\hline & Former Colonies & \multicolumn{5}{|l|}{} \\
\hline China & 0.00 & 0.00 & -0.08 & -0.62 & 4.17 \\
\hline India & 0.00 & -0.03 & 0.25 & -0.23 & 2.18 \\
\hline Indonesia & 0.01 & 0.04 & 0.42 & -0.20 & 2.74 \\
\hline Brazil & 0.07 & 0.28 & 0.89 & 0.85 & 2.18 \\
\hline Mexico & 0.15 & 0.24 & 0.89 & 0.85 & 2.18 \\
\hline United States & 0.14 & 0.73 & 1.56 & 1.61 & 2.21 \\
\hline Ireland & 0.15 & 0.17 & 1.23 & 0.63 & 3.53 \\
\hline
\end{tabular}

Source: Maddison (2006).

Whereas the European colonial powers and the settlement countries, e.g., the US, recorded positive rates of growth of per capita GDP, period growth rates in the colonies were stagnant, if not negative, before their respective independence. ${ }^{1}$

Thus the colonial experience was impoverishing for several colonies. In India itself the effects went beyond the purely economic as the following quote from the Nobel laureate poet Rabindranath Tagore reveals:

Rudely shaken out of my dream I began to realize that perhaps in no other modern state was there such hopeless dearth of the most elementary needs of existence. And all the time before our eyes Japan has been transforming herself into a mighty and prosperous nation. I have also been privileged to witness the unsparing energy with which Russia has succeeded in steadily liquidating ignorance and poverty wiping off the humiliation from the face of a vast

\footnotetext{
${ }^{1}$ In an important work Nurkse (1953) emphasized the difference between the settlement and non settlement countries among the set of colonized countries as involving the method of financing of capital. Whereas the bulk of investment in settlement countries was through equity the non-settlement countries received loans, which they had to service. This debt servicing put onerous burdens on the already fragile economies of the non-settlement colonized countries (Maddison 2006).
} 
continent. I cannot help contrasting two systems of governance: one based on cooperation and the other on exploitation. Thus, while these other countries were marching ahead, India smothered under the dead weight of British administration lay static in her utter helplessness. (Tagore 1941, p. 637)

Table 2 reveals that despite India's dismal economic performance for 350 years India’s GDP per capita in 1950 was higher than China’s. Currently China’s GDP per capita is higher than India's by a factor of almost 3 indicating that since independence India has let the advantage over China slip away. India’s post independence growth story did not have an auspicious start, although growth has accelerated considerably of late. It is thus pertinent to examine India's growth experience in the post independence era in some detail.

For the first thirty years or so after independence India's growth rates were low and highly volatile as economic outcomes depended significantly on agricultural harvests which, in turn, depended on the monsoons. Finance Minister P. Chidambaram’s labelled these three decades as the lost decades for economic growth and poverty alleviation. The first three rows of table 4 illustrate this basic point.

Table 4: Mean Growth Rates of India's Real GNP and their volatility

\begin{tabular}{|l|c|c|}
\hline \multicolumn{1}{|c|}{ Period } & $\begin{array}{c}\text { Mean Annual Growth Rate } \\
\text { (percentages) }\end{array}$ & $\begin{array}{c}\text { Standard Deviation of } \\
\text { Year to Year Growth Rate } \\
\text { (percentages) }\end{array}$ \\
\hline 1951-52 to 1959-60 & 3.58 & 2.62 \\
\hline $1960-61$ to $1969-70$ & 3.91 & 3.64 \\
\hline $1970-71$ to $1979-80$ & 3.05 & 4.16 \\
\hline $1980-81$ to $1989-90$ & 5.65 & 2.27 \\
\hline $1990-91$ to $1999-00$ & 5.83 & 1.97 \\
\hline $1992-93$ to $1999-00$ & 6.46 & 1.16 \\
\hline $2001-02$ to $2005-06^{a}$ & 6.82 & 1.99 \\
\hline $2001-02$ to $2005-06$ (2002-03 excluded) & 7.55 & 1.2 \\
\hline
\end{tabular}

N.B. 2002-03 was a significant drought year and its inclusion raised the standard deviation of the growth rate. If 2002-03 is excluded the average growth for 2001-02 to 2005-06 would have been $7.55 \%$ and the standard deviation 1.2 .

Source: Author's calculation based on data from Reserve Bank of India Handbook of Statistics on the Indian Economy 
Growth picked up significantly since the 1980s. Further, the variability of this growth (as measured by the standard deviation) has come down significantly. Per capita GDP growth which was 1.2 per cent per annum during 1972-82, accelerated to 3.0 per cent during 1982-92 and further to 3.9 per cent during 1992-2002. In recent times it has accelerated even further to over 7 per cent. Hence, the Indian economy has been enjoying high and relatively stable rates of growth for more than a quarter century now. This phase of higher growth was initiated by higher agricultural growth through the Higher Yield Variety Seeds Technology associated with the Green Revolution.

Subsequently a modest program of economic reforms was initiated in the mid 1980s followed by a broader attempt at liberalization and reforms begun in July 1991. These reforms are ongoing.

Recent experience of economic growth (and its sectoral composition) is shown in Table 5 and Figure 1.

Table 5: Growth Rates of Real GDP (\%)

\begin{tabular}{|c|c|c|c|c|c|}
\hline Sector & $\begin{array}{c}1993-94 \text { to } \\
2002-03 \\
\text { (average) }\end{array}$ & $\begin{array}{c}2000-01 \text { to } \\
2005-06 \\
\text { average }\end{array}$ & $2004-05$ & 2005-06 & $2006-07$ \\
\hline 1. Agriculture and Allied Activities & $\begin{array}{c}2.1 \\
(26.5)\end{array}$ & $\begin{array}{c}2.3 \\
(22.2)\end{array}$ & $\begin{array}{r}0.0 \\
(20.2)\end{array}$ & $\begin{array}{c}6.0 \\
(19.7)\end{array}$ & $\begin{array}{c}2.7 \\
(18.5)\end{array}$ \\
\hline 1.1 Agriculture & 2.0 & 2.0 & & & \\
\hline 2. Industry & $\begin{array}{c}6.6 \\
(22.1) \\
\end{array}$ & $\begin{array}{r}6.2 \\
(19.6) \\
\end{array}$ & $\begin{array}{r}8.4 \\
(19.6) \\
\end{array}$ & $\begin{array}{c}8.0 \\
(19.4) \\
\end{array}$ & $\begin{array}{c}10.2 \\
(19.6) \\
\end{array}$ \\
\hline 2.1 Mining and Quarrying & 4.7 & 4.2 & 7.5 & 3.6 & 4.5 \\
\hline 2.2 Manufacturing & 7.1 & 6.9 & 8.7 & 9.1 & 11.3 \\
\hline 2.3 Electricity, Gas and Water supply & 5.2 & 3.8 & 7.5 & 5.3 & 7.7 \\
\hline 3. Services & $\begin{array}{c}7.8 \\
(51.4) \\
\end{array}$ & $\begin{array}{r}8.1 \\
(58.2) \\
\end{array}$ & $\begin{array}{c}10.0 \\
(60.2)\end{array}$ & $\begin{array}{c}10.3 \\
(60.9) \\
\end{array}$ & $\begin{array}{c}11.0 \\
(61.9)\end{array}$ \\
\hline $\begin{array}{l}\text { 3.1 Trade, Hotels, Restaurants, Transport, Storage } \\
\text { and Communication }\end{array}$ & 8.8 & 9.9 & 10.9 & 10.4 & 13.0 \\
\hline $\begin{array}{l}\text { 3.2 Financing, Insurance, Real Estate and Business } \\
\text { Services }\end{array}$ & 8.0 & 7.1 & 8.7 & 10.9 & 11.1 \\
\hline 3.3 Community, Social and Personal Services & 6.9 & 5.8 & 7.9 & 7.7 & 7.8 \\
\hline 3.4 Construction & 5.7 & 8.9 & 14.1 & 14.2 & 9.4 \\
\hline 4. Real GDP at Factor Cost & $\begin{array}{r}6.0 \\
(100) \\
\end{array}$ & $\begin{array}{c}6.4 \\
(100) \\
\end{array}$ & $\begin{array}{c}7.5 \\
(100)\end{array}$ & $\begin{array}{r}9.0 \\
(100) \\
\end{array}$ & $\begin{array}{c}9.2 \\
(100) \\
\end{array}$ \\
\hline
\end{tabular}

Note: Figures in parentheses denote shares in real GDP.

Source: Reserve Bank of India. 
The recent high rate of economic growth in India has been broad-based and no longer dependent on agriculture to the extent during 1950-79. This has raised the mean growth and lent it considerable stability. Agricultural growth has continued to fluctuate considerably even as the share of agriculture in GDP has come down sharply. ${ }^{2}$

Manufacturing growth was high in the initial years of the post reforms period but fell sharply in 2001-02. The subsequent pick-up in 2002-03 was probably because of the lower base in 2001-02. Industrial growth rates have since been robust and have become comparable to service sector growth rates. Growth in mining has been less spectacular. Growth in electricity production has been slow — perhaps reflecting the poor state of electricity generation and, particularly, transmission and distribution in India. The highest and most stable growth sector has been services. Consequently, the share of services in GDP has risen sharply (Figure 1).

Figure 1: Sectoral Composition of India's GDP

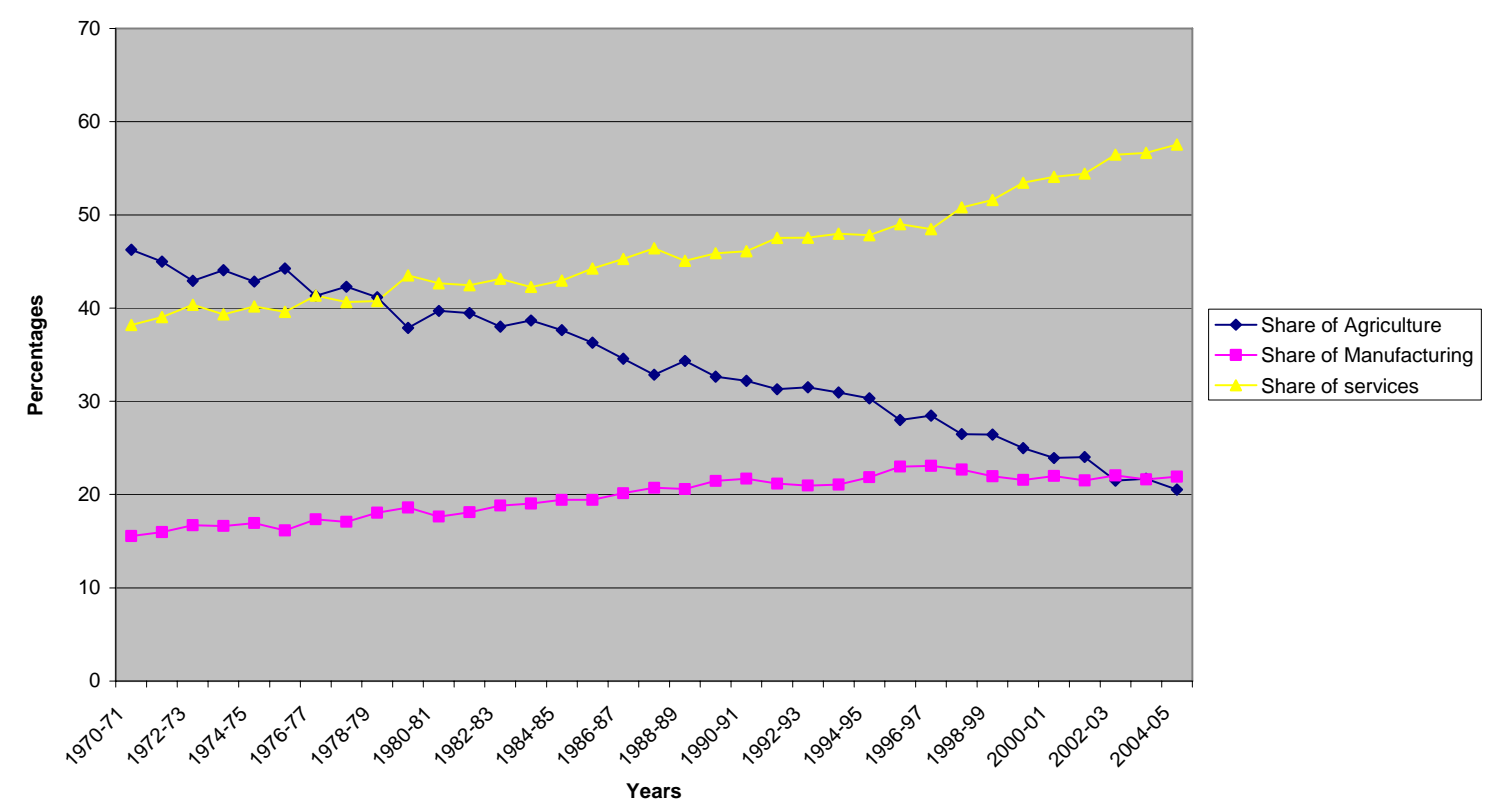

Source: Based on data from Handbook of Indian Statistics (2006), Reserve Bank of India.

\footnotetext{
${ }^{2}$ The share of agriculture in employment is, however, much higher. One of the current important anomalies in the Indian economy is that a sector that produces 22 per cent of GDP employs 65 per cent of the labour force.
} 
As a result of this sustained economic growth India is now a huge market with a large and young population. 95.1 per cent of India's billion plus population is below the age of 65, with the median age being 24.9 years and almost a third of the population younger than 14. A Reuters report estimates that by the time these children enter the labour force India will be a US\$1 trillion plus (at market exchange rates) economy. By some reckoning India's middle class (those earning between US\$2000 to $\$ 22,000$ a year) is 300 million strong. This young labour force is keen to enrich itself quickly, thus saving an investing more, and to compete with the outside world — witness India's persistent double-digit export growth in recent years. With deep domestic markets and the service sector accounting for 31 per cent of exports India's reliance on manufactured exports is lower than many Asian countries. Thus any downturn in the global economy may have less impact on India.

The current phase of high growth is subject to a few constraints (Jha 2005). These include inadequate infrastructure sector, growing regional inequality (which has affected the political consensus for reforms) and low agricultural growth rates which have raised food price relative to prices in general. Notwithstanding these glitches there remains broad-based consensus for economic reforms which augurs well for the continued buoyancy of the economy.

\section{Factors Accelerating Economic Growth in India}

The current high economic growth could well accelerate further as Kelkar (2004) has opined. Contributing to this acceleration is a broad series of reforms including financial sector reforms, increased globalization and widening and deepening of product and financial markets. The impact of such reforms gets reflected in key indicators such as market capitalization of the stock market, the technology and transparency of transactions, the sets of instruments traded, balance sheets of financial institutions and 
the degree of openness of the economy. Concurrently a benign FDI policy framework has permitted greater tie-ups in high technology areas for production for domestic as well as external markets. I now list some key factors (in a growth accounting sense) that have led to the current surge in economic growth in India and have the potential to sustain or even accelerate this growth rate.

\section{Productivity Growth}

The higher GDP growth rate beginning in the 1980s has been accompanied by a sharp acceleration in total factor productivity growth (Table 6).

Table 6: Sources of Growth in India: Aggregate and by Major sectors (\% pa)

\begin{tabular}{|c|c|c|c|c|c|c|c|}
\hline \multicolumn{8}{|c|}{ Aggregate Economy } \\
\hline & & & & \multicolumn{4}{|c|}{ Contribution of } \\
\hline Period & Output & Employment & $\begin{array}{c}\text { Output per } \\
\text { worker }\end{array}$ & $\begin{array}{c}\text { Physical } \\
\text { capital }\end{array}$ & Land & Education & $\begin{array}{c}\text { Factor } \\
\text { productivity }\end{array}$ \\
\hline 1978-04 & 5.4 & 2.0 & 3.3 & 1.3 & 0.0 & 0.4 & 1.6 \\
\hline 1978-93 & 4.5 & 2.1 & 2.4 & 1.0 & -0.1 & 0.3 & 1.1 \\
\hline 1993-04 & 6.5 & 1.9 & 4.6 & 1.8 & 0.0 & 0.4 & 2.3 \\
\hline \multicolumn{8}{|c|}{ Agriculture } \\
\hline 1978-04 & 2.5 & 1.1 & 1.4 & 0.4 & -0.1 & 0.3 & 0.8 \\
\hline 1978-93 & 2.7 & 1.4 & 1.3 & 0.2 & -0.1 & 0.2 & 1.0 \\
\hline 1993-04 & 2.2 & 0.7 & 1.5 & 0.7 & -0.1 & 0.3 & 0.5 \\
\hline \multicolumn{8}{|l|}{ Industry } \\
\hline 1978-04 & 5.9 & 3.4 & 2.5 & 1.5 & & 0.3 & 0.6 \\
\hline 1978-93 & 5.4 & 3.3 & 2.1 & 1.4 & & 0.4 & 0.3 \\
\hline 1993-04 & 6.7 & 3.6 & 3.1 & 1.7 & & 0.3 & 1.1 \\
\hline \multicolumn{8}{|l|}{ Services } \\
\hline 1978-04 & 7.2 & 3.8 & 3.5 & 0.6 & & 0.4 & 2.4 \\
\hline 1978-93 & 5.9 & 3.8 & 2.1 & 0.3 & & 0.4 & 1.4 \\
\hline 1993-04 & 9.1 & 3.7 & 5.4 & 1.1 & & 0.4 & 3.9 \\
\hline
\end{tabular}

Source: Bosworth and Collins (2007).

Table 6 presents data for the period 1978-2004 and the two sub periods: before reforms (1978-93) and after reforms (1993-04). Aggregate productivity growth, driven mainly by a pick up in service sector productivity growth, picked up considerably during 
1993-04 — in fact it more than doubled between 1978-93 and 1993-04. Agricultural growth has stagnated except for the "green revolution” phase of 1978-93.

Rodrik and Subramanian (2004) examine a number of possible explanations for this rise in productivity growth. Such explanations include Keynesian type demand-led expansion in the 1980s, the advent of the Green Revolution, and external and internal liberalization. However, they find empirical support for attitudinal changes in governments in the mid to late 1980s. These administrations, it is argued, began viewing private investment and enterprise more favorably and modest reforms were initiated. This had salutary effects on manufacturing sector productivity and later had substantial spillover effects. Such beneficial synergies were helped by the climate of deregulation and delicensing started in the early 1990s. Other authors have placed a much stronger emphasis on the role of the post 1991 reforms and downplayed the role of policy initiatives of the 1980s. ${ }^{3}$ To be sure, financial sector reforms began only in 1993 and are yet to be completed.

\section{Improvements in Labour Supply}

India's labour supply is undergoing fundamental changes. In 2000 the proportion of the Indian population in the working age group (15-64 age bracket) was 60.9\%. The UN's Population Division has projected that this ratio will surpass the proportion of Japanese in this age group by 2012 and climb to over $66 \%$ in 30 years. At that time it is poised to overtake China’s population in the same age group.

\footnotetext{
${ }^{3}$ There has been a debate of sorts about whether attitudinal changes in the government bureaucracy or actual policy changes are better explanations for the acceleration in economic growth in India. In a country with an autarkic trade regime and a highly centralized administrative structure, attitudinal changes may well be the hardest to make. Hence, both policy measures as well as attitudinal changes should be regarded as essential as well as complementary explanations for this surge in the rate of growth.
} 
At the same time a quiet revolution is taking place in nutritional status in India with calorie and other macro and micro nutrient deficiency on the decline. According to the 2001 Census during the period 1991 to 2001 the literacy rate climbed from $51.54 \%$ to $65.38 \%$ in the aggregate, from $63.3 \%$ to $75.85 \%$ for males and from 38.79 to 54.16 \% for females. Thus India’s labour force is younger, better nourished and has more skills than before. These changes imply substantial quality improvements in the India's labour force. Economic theory and international experience leads us to believe that this will lead to sharp rises in labour productivity and an upward shift in the trend long run rate of growth of the Indian economy.

\section{Higher Savings and Investment for Enhanced Economic Growth}

Central to the growth success story has been a steady rise in India's saving and investment rates (Table 7).

Table 7: Savings and Investment in India

\begin{tabular}{|l|c|c|c|c|c|c|c|}
\hline $\begin{array}{l}\text { Savings and Investment (Base: 1999-2000) } \\
\text { As \% of GDP at Current Market Prices }\end{array}$ & $1999-00$ & $2000-01$ & $2001-02$ & $2002-03$ & $2003-04$ & $2004-05$ & $\begin{array}{c}2005-06 \\
\text { (est.) }\end{array}$ \\
\hline & 24.8 & 23.4 & 23.5 & 26.4 & 29.7 & 31.1 & 32.4 \\
\hline Gross Domestic Savings, of which & -0.8 & -1.9 & -2.0 & -0.6 & 1.2 & 2.4 & 2.0 \\
\hline a) Public & 25.6 & 25.3 & 25.5 & 27.0 & 28.5 & 28.7 & 30.4 \\
\hline b) Private, of which & 21.1 & 21.0 & 21.8 & 22.7 & 23.8 & 21.6 & 22.3 \\
\hline i) Household, of which & 10.6 & 10.2 & 10.8 & 10.3 & 11.3 & 10.2 & 11.7 \\
\hline Financial & 10.5 & 10.8 & 10.9 & 12.4 & 12.4 & 11.4 & 10.7 \\
\hline Physical & 4.5 & 4.3 & 3.7 & 4.2 & 4.7 & 7.1 & 8.1 \\
\hline ii) Private corporate & 25.9 & 24.0 & 22.9 & 25.2 & 28.0 & 31.5 & 33.8 \\
\hline $\begin{array}{c}\text { Gross Domestic Investment, } \\
\text { of which }\end{array}$ & 7.4 & 6.9 & 6.9 & 6.1 & 6.3 & 7.1 & 7.4 \\
\hline Public & 17.9 & 16.5 & 16.3 & 18.4 & 19.4 & 21.3 & 23.6 \\
\hline Private & 0.8 & 0.7 & 0.6 & 0.6 & 0.9 & 1.3 & 1.2 \\
\hline Valuables & 23.4 & 22.8 & 23.0 & 23.8 & 24.8 & 26.3 & 28.1 \\
\hline $\begin{array}{l}\text { Gross Fixed Capital Formation, } \\
\text { of which }\end{array}$ & 1.9 & 0.6 & 0.2 & 0.7 & 0.8 & 2.0 & 2.9 \\
\hline Changes in stocks & 0.8 & 0.7 & 0.6 & 0.6 & 0.9 & 1.3 & 1.2 \\
\hline Valuables & -1.1 & -0.6 & 0.6 & 1.2 & 1.6 & -0.4 & -1.3 \\
\hline Saving - Investment & -8.2 & -8.8 & -8.9 & -6.6 & -5.2 & -4.7 & -5.4 \\
\hline Public & 7.7 & 8.8 & 9.2 & 8.6 & 9.2 & 7.4 & 6.9 \\
\hline Private & & & & & & \\
\hline
\end{tabular}

Source: Economic Survey, Government of India, 2006-07. 
Savings have risen from 23.4 per cent of GDP in 2000-01 to 32.4 per cent in 2005-06 whereas during the same period investment rose from 24 per cent of GDP to 33.8 per cent of GDP. Public sector saving turned positive in 2003-04 indicating improved tax and budgetary performance. With 33.8 per cent investment in 2005-06 India was able to obtain 9 per cent GDP growth whereas China obtains 9 per cent growth with investment rates of over 40 per cent. Thus the productivity of capital is higher in India than in China.

\section{Falling Fiscal deficits and rising public savings}

As India seeks to accelerate its growth rate even further, raising the saving and investment rates by lowering fiscal deficits will be key. India needs to streamline public subsidies and increase tax revenues in order to reduce, if not eliminate, public dissaving in order to boost economic growth. In recent times, particularly since 2003, India's fiscal deficit situation has improved (Table 8).

Table 8: India: Key Fiscal Indicators (\%of GDP)

\begin{tabular}{|c|c|c|c|}
\hline Year & Primary Deficit & Revenue Deficit & Gross Fiscal Deficit \\
\hline \multicolumn{4}{|c|}{ Central Government } \\
\hline $2002-03$ & 1.1 & 4.4 & 5.9 \\
\hline 2003-04 & -0.03 & 3.6 & 4.5 \\
\hline $2004-05$ & 0.06 & 2.5 & 4.01 \\
\hline $2005-06$ & 0.5 & 2.6 & 4.1 \\
\hline 2006-07 (BE) & 0.2 & 2.1 & 3.8 \\
\hline \multicolumn{4}{|c|}{ States } \\
\hline $2002-03$ & 1.3 & 2.2 & 4.2 \\
\hline 2003-04 & 1.5 & 2.2 & 4.5 \\
\hline $2004-05$ & 0.7 & 1.2 & 3.5 \\
\hline $2005-06$ & 0.7 & 0.5 & 3.2 \\
\hline 2006-07 (BE) & 0.3 & 0.1 & 2.8 \\
\hline \multicolumn{4}{|c|}{ Combined } \\
\hline $2002-03$ & 3.1 & 6.7 & 9.6 \\
\hline 2003-04 & 2.1 & 5.8 & 8.5 \\
\hline $2004-05$ & 1.4 & 3.7 & 7.5 \\
\hline $2005-06$ & 1.6 & 3.1 & 7.5 \\
\hline 2006-07 (BE) & 0.9 & 2.3 & 6.6 \\
\hline
\end{tabular}

Note: $\quad \mathrm{BE}=$ budget estimates

Source: RBI. 
Though fiscal deficits have been coming down successive reductions have become harder to achieve. It is unclear whether the government's goal of achieving zero revenue deficit by 2009 will be achieved. Concurrently public debt has climbed to over 80 per cent of GDP. External debt is low, with a large share in long term debt. Hence pressures on the exchange rate because of high external debt are minimal. In addition India’s foreign exchange rate reserves on 25 May 2007 stood at US\$204.9 billion, a substantial part of which comes from sterilisation operations to keep the exchange rate competitive for exporters.

\section{India's External Sector Performance}

The recent acceleration in India's economic growth has been associated with greater economic integration with the global economy. India missed the first phase of trade liberalization in the post-War period but is has not done so this time around. Indian manufacturing tariffs are now low by world developing country standards: $12.5 \%$ and Indian anti-dumping appears to be slowing down. India is far less dependent on tariffs for government revenue but agricultural tariff reduction has not kept pace with industrial tariff liberalization. A necessary but not sufficient condition for it to be reversed would be agricultural protection cuts in developed countries. India's exports have surged ${ }^{4}$ and India’s export basket is geared towards high value added items such as engineering goods (Table 9).

\footnotetext{
${ }^{4}$ India’s exports grew at 28.2 per cent and 29.8 per cent in 2004 and 2005 respectively compared to 21.2 per cent and 13.9 per cent for world exports, 27.3 per cent and 21.8 per cent for developing country exports and 35.3 per cent and 28.4 per cent for China for the two years.
} 
Table 9: Commodity Composition of India's Exports

\begin{tabular}{|l|c|c|c|c|c|c|}
\hline & \multicolumn{3}{|c|}{ Percentage Share } & \multicolumn{3}{c|}{ Growth Rate (in US \$ terms) } \\
\hline Commodity Group & $2004-05$ & $2005-06$ & $\begin{array}{c}2006-07 \\
\text { (April-October) }\end{array}$ & $2004-05$ & $2005-06$ & $\begin{array}{c}2006-07 \\
\text { (April-October) }\end{array}$ \\
\hline $\begin{array}{c}\text { 1. Primary Products, } \\
\text { of which }\end{array}$ & 16.0 & 15.4 & 13.9 & 36.2 & 18.9 & 17.3 \\
\hline Agriculture \& allied & 10.5 & 10.2 & 9.9 & 11.7 & 19.8 & 25.4 \\
\hline Ores \& Minerals & 5.5 & 5.2 & 4.0 & 136.5 & 17.4 & 1.1 \\
\hline $\begin{array}{c}\text { 2. Manufactured Goods, } \\
\text { of which }\end{array}$ & 74.2 & 72.0 & 69.0 & 24.9 & 19.6 & 17.6 \\
\hline Textiles incl. RMG & 14.9 & 14.5 & 9.8 & 5.3 & 20.4 & 11.7 \\
\hline \begin{tabular}{c} 
Gems \& Jewellery \\
\hline Engineering goods
\end{tabular} & 16.5 & 15.1 & 12.9 & 30.2 & 12.8 & -4.4 \\
\hline $\begin{array}{c}\text { Chemicals \& related } \\
\text { products }\end{array}$ & 12.2 & 11.6 & 10.4 & 33.9 & 17.3 & 14.8 \\
\hline Leather \& Manufactures & 2.9 & 2.6 & 1.8 & 12.0 & 11.1 & 5.7 \\
\hline $\begin{array}{c}\text { Handicrafts (incl. } \\
\text { carpet handmade) }\end{array}$ & 1.2 & 1.2 & 1.0 & -7.0 & 30.2 & -7.3 \\
\hline $\begin{array}{c}\text { 3. Petroleum, Crude \& } \\
\text { products (incl. coal) }\end{array}$ & 8.5 & 11.5 & 16.3 & 91.2 & 66.2 & 85.3 \\
\hline Total exports & 100.0 & 100.0 & 100.0 & 30.8 & 23.4 & 25.3 \\
\hline
\end{tabular}

Source: Economic Survey Government of India 2006-07

India's trade balance, although substantially in the red, has been covered by inflows from Non Resident Indians and software exports leading to more modest current account deficits. This along with substantial foreign exchange reserves ensures reasonable macroeconomic stability.

\section{Two Facets of the new India - A Dynamic Sector and a Laggard}

The surge in India's growth rate has led to rapid growth of some industries whereas others have lagged behind. Table 10 provides illustration of automobiles — a dynamic sector of the new India.

Growth in automobiles has been well spread out over all categories and export performance has been spectacular. On the other hand agriculture has been lagging. Table 11 indicates average growth in area, production and yield under foodgrains, non foodgrains and all crops. 
Table 10: India: Automobile Production and Export

\begin{tabular}{|l|c|c|c|c|c|c|}
\hline \multicolumn{7}{|c|}{ Automobile Production (Numbers in 000) } \\
\hline & $2000-01$ & $2001-02$ & $2002-03$ & $2003-04$ & $2004-05$ & $2005-06$ \\
\hline Passenger Cars & 513 & 564 & 609 & 842 & 961 & 1046 \\
\hline Multi-utility vehicles & 128 & 106 & 112 & 146 & 249 & 263 \\
\hline Commercial vehicles & 157 & 163 & 204 & 275 & 350 & 391 \\
\hline Two wheelers & 3,759 & 4,271 & 5,076 & 5,625 & 6,527 & 7,600 \\
\hline Three wheelers & 203 & 213 & 277 & 341 & 374 & 434 \\
\hline Total & 4,759 & 5,316 & 6,280 & 7,229 & 8,461 & 9,735 \\
\hline Growth (\%) & -2.00 & 11.70 & 18.60 & 15.12 & 16.80 & 14.97 \\
\hline & Automobile Export (Numbers in 000) & & \\
\hline & $2000-01$ & $2001-02$ & $2002-03$ & $2003-04$ & $2004-05$ & $2005-06$ \\
\hline Passenger Cars & 23 & 50 & 71 & 126 & 161 & 170 \\
\hline Multi-utility vehicles & 4 & 3 & 1 & 3 & 6 & 5 \\
\hline Commercial vehicles & 14 & 12 & 12 & 17 & 30 & 41 \\
\hline Two wheelers & 111 & 104 & 180 & 265 & 367 & 513 \\
\hline Three wheelers & 16 & 15 & 43 & 68 & 67 & 77 \\
\hline Total & 168 & 185 & 307 & 479 & 620 & 806 \\
\hline Growth (\%) & 20.24 & 9.74 & 65.35 & 55.98 & 31.25 & 28.03 \\
\hline
\end{tabular}

Source: Economic Survey: Government of India 2006-07

Table 11: Average Growth rates of Area, Production and Yield under Foodgrains, Non-foodgrains and All Crops. (percentages)

\begin{tabular}{|c|c|c|c|c|c|c|c|c|c|}
\hline \multirow[b]{3}{*}{$\begin{array}{l}1950-51 \text { to } \\
1993-94\end{array}$} & \multicolumn{3}{|c|}{ Foodgrains } & \multicolumn{3}{|c|}{ Non-foodgrains } & \multicolumn{3}{|c|}{ All crops } \\
\hline & Area & Production & Yield & Area & Production & Yield & Area & Production & Yield \\
\hline & 0.53 & 2.99 & 2.03 & 1.51 & 3.33 & 1.30 & 0.81 & 3.05 & 1.72 \\
\hline $\begin{array}{l}1993-94 \text { to } \\
2004-05\end{array}$ & 0.30 & 1.44 & 0.90 & 0.34 & 2.63 & 1.49 & 0.33 & 1.72 & 1.11 \\
\hline $\begin{array}{l}1950-51 \text { to } \\
1959-60\end{array}$ & 1.64 & 2.79 & 0.99 & 2.06 & 3.13 & -0.25 & 1.91 & 2.81 & 0.56 \\
\hline $\begin{array}{l}1960-61 \text { to } \\
1969-70\end{array}$ & 0.63 & 2.96 & 2.01 & 0.97 & 3.08 & 1.35 & 0.71 & 2.96 & 1.71 \\
\hline $\begin{array}{l}1970-71 \text { to } \\
1979-80\end{array}$ & 0.19 & 1.38 & 0.53 & 0.75 & 1.78 & 0.98 & 0.32 & 1.44 & 0.65 \\
\hline $\begin{array}{l}1980-81 \text { to } \\
1989-90\end{array}$ & -0.02 & 3.33 & 2.88 & 1.10 & 3.89 & 2.24 & 0.24 & 3.45 & 2.57 \\
\hline $\begin{array}{l}1990-91 \text { to } \\
1993-94\end{array}$ & -0.80 & 2.03 & 2.00 & 2.40 & 3.18 & 1.20 & 0.08 & 2.45 & 1.65 \\
\hline $\begin{array}{l}1950-51 \text { to } \\
1989-90\end{array}$ & 0.61 & 2.61 & 1.60 & 1.22 & 2.97 & 1.08 & 0.79 & 2.66 & 1.37 \\
\hline $\begin{array}{l}1990-91 \text { to } \\
2004-05\end{array}$ & -0.07 & 1.64 & 1.27 & 1.03 & 2.81 & 1.39 & 0.25 & 1.96 & 1.29 \\
\hline
\end{tabular}

Source: Author's computation based on Reserve Bank of India' Handbook of Statistics on the Indian Economy. 
Even of we define the pre-reform period to go far back as the 1950s, when agricultural operations were subject to very high risks, except for the yield of non-foodgrains the performance in respect of rates of growth of area, production and yield was worse in the post reform period 1990-91 to 2004-05. Except for the growth of area under foodgrains performance during the 1980s was the best. The Green Revolution era was significant for Indian agriculture in more ways than one.

A key reason for the stagnation of growth in agriculture is the stagnation of agricultural investment (Figure 2).

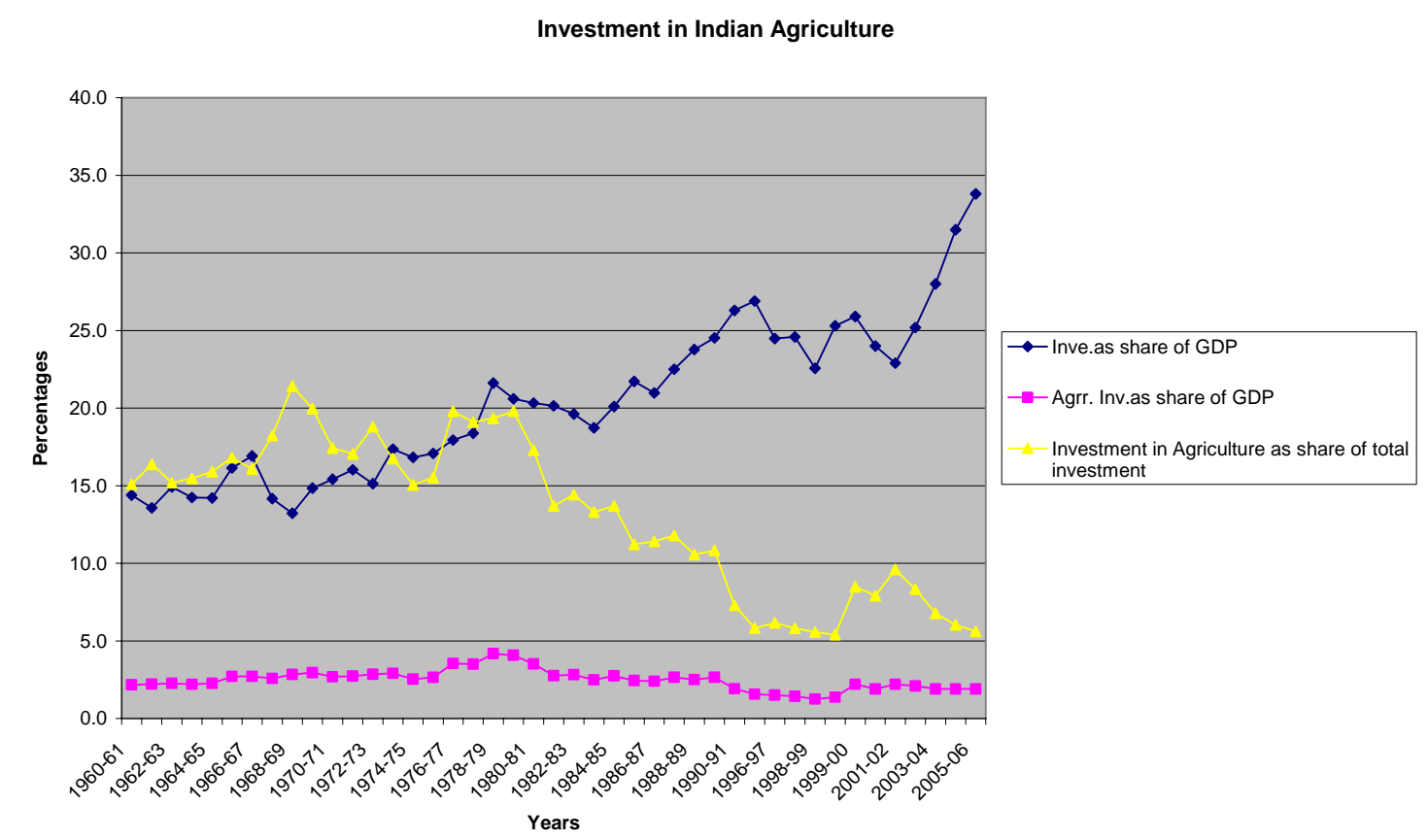

Figure 2: Investment in Indian Agriculture

Source: Computed from figures provided by Reserve Bank of India.

As Figure 2 shows whereas investment as a proportion of GDP has been on a rising trend since the 1970s agricultural investment as a share of total investment has been falling since the 1980s. There was a mild revival between 1999-00 and 2002-03 but, since then, agricultural investment as a proportion of GDP has resumed its downward trend. Agricultural investment as a proportion of GDP has also been falling. 
However, subsidies for agriculture have risen sharply (Figure 3) indicating a a preference for the short term.

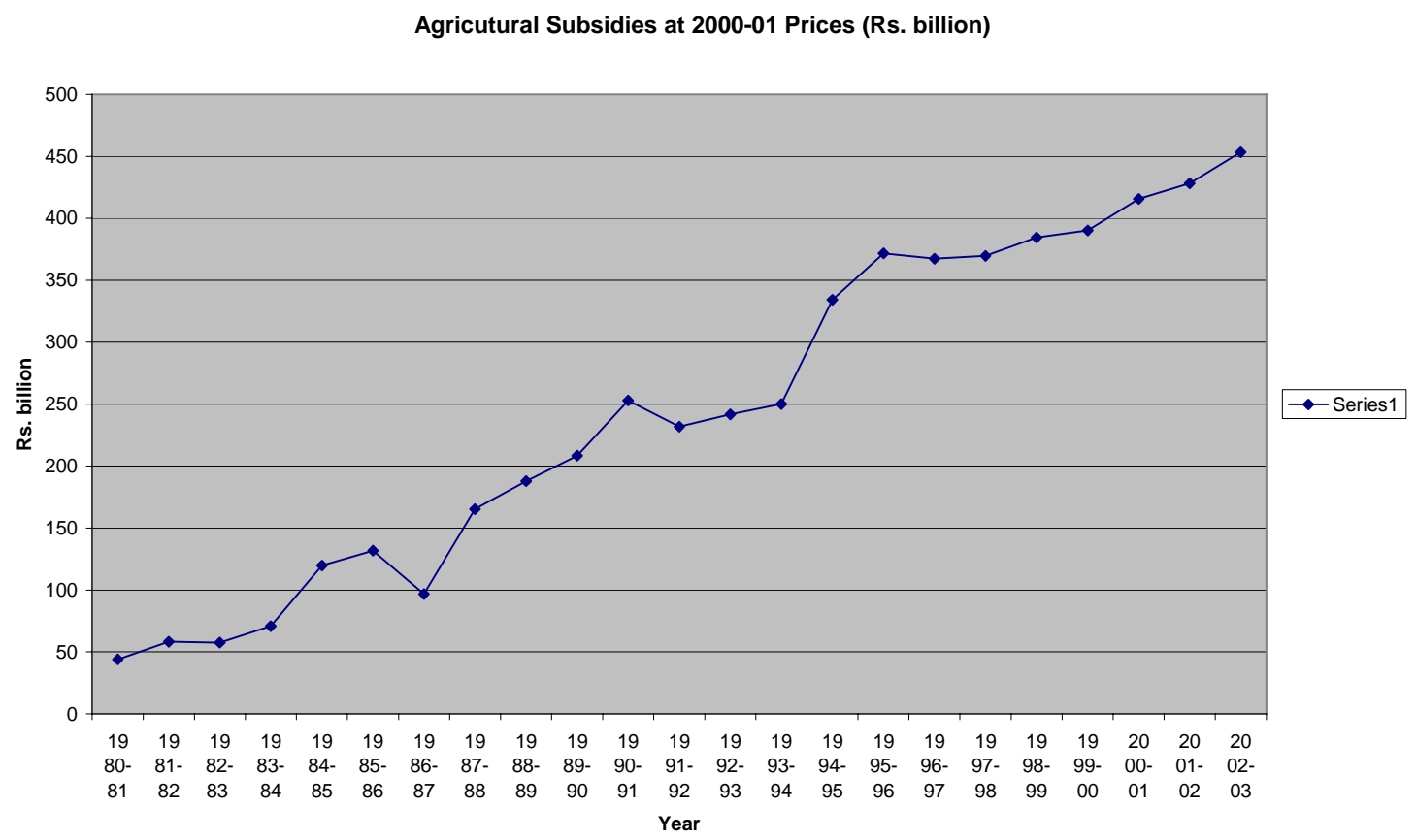

Figure 3: Agricultural Subsidies in India at 2000-01 prices (Rs. Billion)

Source: Computed from Mullen et al. (2005).

Given that more than 60 per cent of India’s population gets its livelihood from agriculture, the lacklustre performance in agriculture presents an important challenge.

\section{Conclusions}

This chapter has provided a broad overview of the Indian growth process and underlined the basic contention that the Indian economy has shown remarkable resilience even as it seeks opportunities for higher economic growth. India's experience with colonialism was not only deleterious for economic growth but also for what may loosely be called the Indian mindset. For decades India remained a low performing economy not only in terms of growth but also in terms of dynamism, scoring low on every index of entrepreneurship and innovation. However, recent advances in technological innovation 
(including in the rural sector) have been spectacular and, since technological innovation is often subject to increasing returns to scale, are indicative of the considerable potential for such growth in the years ahead. At the institutional level the National Innovation Foundation is building a national register of grassroots innovation and traditional knowledge and integrating its activities with micro-finance ventures; the Rural Innovation Network integrates its activities with local engineering colleges and technical schools. Academia-industry alliances are growing rapidly with 50 of India's 250 odd universities being active in such liaisons including consultancies, joint ventures, and even 'blue-skies' projects that entail industry sponsorship of research in an area where the outcome is not clear.

Technological innovation in India has gone beyond the production stage to conception and incubation. The private sector is often taking a lead in such efforts with venture capitalists grooming potential entrepreneurs to think differently with a global understanding of technology and markets and with sensitivity to challenges of high growth businesses in critical areas such as aerospace engineering, development of light combat aircraft, fibre-optics and other frontline areas of research for innovation.

The Council for Scientific and Industrial Research has launched the ambitious five-year New Millennium Indian Technology Leadership Initiative to bring together industry and academia to focus on innovation in 14 niche areas. An important aspect of India's recent economic growth has been the use of India's advantage in the service to enhance competitiveness in manufacturing. Recently published research reveals that advantages of India's well-trained and plentiful labour force are being utilized in the area of services and product customization to enhance manufacturing business models. This procedure differentiates Indian innovation from their Chinese counterparts and facilitates a global reach since few others are following this model.

These advances in innovation have resulted in high rates of productivity growth which combined with improvements in labour supply and higher savings and investment 
and high performing export sector have sustained high rates of economic growth over the past 25 years.

Further, the Indian state consolidated itself further. Foreign Policy Magazine (2007) compiling an Index of Failed States (IFS) has noted that India is one of the stronger nations in the world where a top rank (for Sudan) spells a completely failed state and a bottom rank (Norway at 177) denotes stability and affluence. India’s ranking is 110 in the 2007 IFS suggesting that India's nation-building abilities and institutional strength have gained recognition. In 2005, India was ranked below China, at 76. In 2007, both China and Russia are ranked at 62, while India's social, economic and military metrics have propelled it to 110 . Further, Indian entrepreneurs have retained their place as the world's most optimistic business owners for the fourth year in a row on the back of continuing economic reforms, global business advisory firm Grant Thornton said in its 2007 report.

These and other indicators have led the wider international community to recognise India for what it has become: a country with the physical capital, young; skilled and disciplined labour force and a culture of innovation. It has to be emphasized that this change has not come about by an uncritical mimicking of the successful economies of the West. Even a cursory comparison of the conditions under which the West grew and India is growing would convince one of the folly of this presumption. India is growing in a climate in which it faces a regulated international trade sector and pressures on the environment. Many countries in the West grew by augmenting their savings from resources taken from the colonies and did not have to bother about compliance with industrial pollution standards. While India was forced to absorb manufactures goods from Europe and textiles from Lancashire in the heyday of the 
Industrial Revolution, today India faces potential backlash in its export markets. Since both India and the Western world are concentrating on services Indian exports of services and outsourcing of business services from the West to India lead to populist demands for protectionism against India in the West. These are only some of the many differences in the growth experiences of India and the West. India's growth story is unique to herself. The country has learnt to be resilient in the face of a myriad of shocks even as it kept strengthening the fundamental drivers of economic growth. This is why the Indian growth story has to be taken seriously as an independent model from which the good economic news and the lessons for other countries will continue to flow in the foreseeable future.

\section{References:}

Bosworth, B. \& S. Collins (2007) “Accounting for Growth: Comparing China and India” NBER Working Paper no. 12943, Cambridge, Massachusetts.

Clydesdale, G. (2007) "What Happened to Indian Prosperity? The Systemic Loss of Prosperity" Journal of the Asia Pacific Economy, vol.12, no.3, pp. 305-328.

Foreign Policy Magazine (2007) “The Index of Failed States 2007” July-August.

Jha, R. (2005) “The Political Economy of Recent Economic Growth in India” in R. Jha (ed.) Economic Growth, Economic Performance, Economic and Welfare in South Asia. Basingstoke, UK: Palgrave Macmillan.

Kelkar, V. (2004) India on the Growth Turnpike, 2004 K.R. Narayanan Oration, Australia South Asia Research Centre, The Australian National University, Canberra.

Maddison, A. (2006) The World Economy, OECD: Paris, Development Centre Studies

Mullen, K., Orden, D. and A. Gulati (2005), “Agricultural Policies in India: Producer Support Estimates 1985-2002”, MTID Discussion Paper No. 82, IFPRI, Washington D.C.

Nurkse, R. (1953) Problems of Capital Formation in Underdeveloped Countries, Oxford: Blackwell

Rodrik, D. \& A. Subramanian (2004) "From Hindu Growth to Productivity Surge: The Mystery of the Indian Growth Transition” IMF Working Paper WP/04/77, Washington DC.

Tagore, R. (1941) “Crisis in Civilization”available at http://www.vbharat.ernet.in/html/crisis_in_civilization.html Bengali version Sabhyatar Sankat, Rabindra Rachanavali vol.26, Calcutta: Vishwabharati. 